\title{
GENEZA FILOZOFICZNEJ IDEI QUEER WOBEC PODSTAW ANTROPOLOGICZNYCH KATOLICKIEJ NAUKI SPOLECZNEJ
}

DOI: http://dx.doi.org/10.12775/SPLP.2021.021

\section{Streszczenie}

Artykuł podejmuje próbę odpowiedzi na pytania o podstawy filozoficzne i myślowe queer theory oraz prezentuje głównych myślicieli, którzy wywarli znaczący wpływ na rozwój performatywności w ruchach feministycznych. Przedstawiam genezę i opis procesu subwersji oraz dekonstrukcji pojęć takich jak płeć, małżeństwo, kobiecość, heteronormatywność, binarność, seksualność i ostatecznie queer. Polemizuję między innymi z poglądami Judith Butler, która próbuje opisać pojęcie queer, charakteryzując je jako odtwarzanie performatywnych wypowiedzi, interpolowanych, stanowiących moc wiążącą przypadkowych, obalalnych, rozsadzających istniejące konwencje. Artykuł zestawia powyższe zagadnienia z Katolicką Nauką Społeczną i antropologią Kościoła Katolickiego. Wskazuje na obszary tworzącej się na naszych oczach nowej rzeczywistości.

Slowa kluczowe: queer, nauczanie społeczne Kościoła, personalizm, płeć, gender 


\title{
THE ORIGINS OF QUEER IDEAS IN THE LIGHT \\ OF THE ANTHROPOLOGICAL BASIS \\ OF THE CATHOLIC SOCIAL TEACHING
}

\begin{abstract}
The paper searches for the philosophical and conceptual fundaments of the queer theory and its influential proponents who inspired the growth of the feminist movement initiatives. I present the process of subversion and deconstruction of such notions as sex, marriage, feminity, heteronormativity, binary identity, sexuality and, finally, queer. The article contains a critique of Judith Butler's ideas. She presented the term ,queer" as reproduction of interpolated random and fluid statements which reject the traditional order of things. The paper also juxtaposes these propositions with the Catholic Social Teaching and anthropology and explores the areas where the on-going intellectual processes shape our reality.
\end{abstract}

Keywords: queer, Catholic Social Teaching, personalism, sex, gender

W ostatnich latach powstało wiele publikacji na temat ruchów działających na rzecz kobiet, rewolucji seksualnej, płci kulturowo-społecznej-gender oraz coraz częściej queer. W niewielkim stopniu prace zwracają uwagę na podstawy antropologiczne i filozoficzne, na jakich zbudowane są powyższe poglądy, a niemalże nie mówi się i nie bada ich oddziaływania i skutków na życie człowieka oraz społeczeństwa. Queer jest nowym kierunkiem myśli, funkcjonującym w przestrzeni akademickiej od lat 90. XX wieku, w szerszej przestrzeni publicznej od kilkunastu lat. Gender i queer mają istotny związek z ruchem feministycznym, który zmieniał się w czasie i przebiegał w trzech falach, ulegając wpływom wielu myślicieli i filozofów. Nie jest i nie był jednorodnym ruchem ${ }^{1}$. Ruch feministyczny drugiej i trzeciej fali miał ważny wpływ na powstanie takich kierunków ideowych jak gender i queer. Pojęcia dotychczas stosowane ulegały subwersji i były etapami włączanymi do głównego nurtu mainstreamu. Warto zasygnalizować, iż część myślicieli trzeciej fali feminizmu zaczęło podważać istotę feminizmu i wypracowane ideologie studiów gay, lesbian, woman 's studia, poprzez wprowadzanie idei różnorodności i nienormatywności, a także performatywności. Dotyczy to szczególnie zachowań i aktów z pogranicza, które nie mieszczą się w normatywnym, czyli dualnym pojęciu męskości i kobiecości oraz heteronormatywności. Nastąpiło

Por. D. Gronold, B. Hipfl, L. Pedersen, Teaching with the Third Wave New Feminists'Explorations of Teaching and Institutional Contexts, Wydawnictwo Stockholm University, Utrecht 2009, s. 17-34. 
stopniowe wyróżnienie i przeakcentowanie płci kulturowej-gender, kosztem płci biologicznej - sex, której wpływ ograniczono lub eliminowano z kształtowania tożsamości płciowej i orientacji psychoseksualnej osoby². Kościół katolicki nie pozostał obojętny na kwestię tożsamości płciowej i orientacji psychoseksualnej, podkreślając, iż człowiek jest „dogłębnie przeniknięty płciowością”, co ma ogromne znaczenie dla tego, kim jest i jak funkcjonuje w społeczeństwie ${ }^{3}$. Nauczycielski Urząd Kościoła wypowiedział się słowami papieży Pawła VI, Jana Pawła II, Bendykta XVI oraz Franciszka i opiera się na solidnych podstawach antropologicznych, które można streścić we fragmencie Stworzył Bóg człowieka na swój obraz $(\operatorname{Rdz} 1,27)^{4}$. Godność człowieka i jego natura oraz integralność jego psychiki i somatyki umożliwia właściwe funkcjonowanie człowieka. Jest to zarazem płaszczyzna, która stanowi przedmiot wzajemnych nieporozumień i sporów ${ }^{5}$. Człowiek jest więc istotą materialną i duchową zarazem - jest holistyczną całością. Niniejszy artykuł ma na celu zaprezentowanie antropologii, jaka stoi u podstaw queer oraz środowisk i myślicieli, którzy wywarli znaczący wpływ na badany kierunek. Ma także zwrócić uwagę na wątpliwości, zagrożenia i wyzwania, jakie wynikają z przyjętych poglądów queer dla antropologii chrześcijańskiej i katolickiej nauki społecznej. W pracy zostanie ukazana geneza ruchów feministycznych i wpływ liderów tego ruchu na powstanie i myśl gender i queer.

\section{QUEER, GENEZA I GŁÓWNE ZAŁOŻENIA W ŚWIETLE RUCHÓW KOBIECYCH}

Przełom XVIII i XIX wieku był burzliwym okresem na kontynencie europejskim. Powstało i rozwijało się wówczas wiele dziedzin nauki, sztuki, filozofii i ideologii, ale też nastąpił okres walki o ducha narodu i pozycję Kościoła w społeczeństwie i w życiu człowieka. Prądy myślowe wyzwoliły niespotykane siły, których kierunek niejednokrotnie burzył dotychczasowy porządek zarówno feudalno-monarchiczny, jak i relację sacrum i profanum. Wiele nurtów myślowych,

2 Por. B. Wieczorek, Homoseksualizm. Przeglad światowych analiz i badań. Przyczyny, objawy, terapia, aspekty społeczne, Wydawnictwo Fronda, Warszawa 2018, s. 763-784. Znajdziemy tam przegląd teorii rozwoju psychoseksualnych.

3 PH 1.

4 Zarówno gender jak i queer, jako pojęcia z którymi związane są omawiane zagadnienia, o których będzie mowa w dalszej części artykułu, wymagają badań i jako takie powinny stanowić przedmiot badania naukowego. Natomiast inaczej prezentuje się kwestia, na którą zwrócił uwagę papież Benedykt XVI i Franciszek, mianowicie gender (queer) mogą być prezentowane jako pewna idea i postulat propagowania poglądów podważających lub odrzucających prawdę, naturę, moralność, relację sex/gender.

5 Por. K. Wojtyła, Osoba i czyn, Wydawnictwo Polskie Towarzystwo Teologiczne, Kraków 1969, s. 242-244. 
takich jak: socjalizm, komunizm, liberalizm, spirytualizm, materializm, ewolucjonizm, idealizm, pozytywizm, na wielu płaszczyznach podważało ideę Boga i boskości, przyczyniając się do ideowych zmian społecznych. Pomimo oficjalnych wypowiedzi Kościoła, między innymi Piusa VI w deklaracji Quod aliquantum, Piusa IX w encyklice Quanta Cura i Syllabusie, Leona XIII w Rerum novarum, rola i autorytet Kościoła w wielu kręgach politycznych i społecznych zostały mocno nadszarpnięte ${ }^{6}$.

Początki działań ruchów kobiecych możemy odnotować pod koniec XVIII wieku i są one związane z nieśmiałą walką o prawa wyborcze oraz uczestnictwo w życiu społecznym kobiet, których rola sprowadzała się do sfery prywatnej. Do ruchów walczących o swoje prawa przyłączyły się ruchy kobiece, wśród których wymienić możemy takie osoby, jak Mary Wollstonecraft, Abigail Smith Adams oraz Olympia de Gouges. Ich głównym celem było uzyskanie praw wyborczych? Zarówno idea gender jak i queer ma silny związek z ruchem feministycznym i została wypracowana jako kontynuacja postulatów osób wywodzących się lub należących do tej grupy. Początkowe działania określano jako pierwszą falę feminizmu, która oprócz praw wyborczych miała zagwarantować kobietom prawa do edukacji i rozwodów. Działania feministyczne przybierały czasami formę agresywną, przykładem jest ruch sufrażystek Women's Social Political Union z liderką Emmeline Pankhurst ${ }^{8}$. Kluczową postacią dla rozwoju pierwszej fali feminizmu była Margaret Sänger - pionierka i założycielka Amerykańskiej Ligi Kontroli Urodzeń (ABCL) - 1921 rok. Nazwa (ABCL) została zmieniona na International „Planned Parenthood Federation”. Kliniki Sänger propagowały eugenikę, aborcję, antykoncepcję - czyli kontrolę urodzeń.

Wiele postulatów ruchu pierwszej fali zostało spełnionych - wspomniane prawa wyborcze wprowadzono w całej Europie w XX wieku ${ }^{10}$. Druga fala feminizmu przypada na lata 50/60. XX wieku. Można przyjąć, że początkiem tego etapu było opublikowanie książki Druga płeć Simone de Beauvoir. Myśl Simone ,nie rodzimy się kobietami - stajemy się nimi”, weszła do kanonu myśli feministycznych, genderowych i queerowych ${ }^{11}$. Początki drugiej fali feminizmu są związane z postępującym dobrobytem po II wojnie światowej, z silnym rozwojem gospodarczym

6 Por. Piusa XI, Encyklika Quanta cura i Syllabus papieża Piusa XI, Wydawnictwo ANTYK, Komorów 1998, s. 45-46.

7 Por. A. Łebkowska, Gender, w: Kulturowa teoria literatury. Główne pojęcia i problemy, Wydawnictwo Universitas, Kraków 2012, s. 373.

8 Por. J. Hannam, Feminizm, Wydawnictwo Zysk i S-ka, Poznań 2010r, s. 76-83.

9 Por. G. Kuby, Globalna rewolucja seksualna. Likwidacja wolności w imię wolności, Wydawnictwo Homo Dei, Kraków 2012, s. 32-35.

10 Por. Ł. Wawrowski, Polityka równych szans. Instytucjonalne mechanizmy zwiększania partycypacji kobiet w strukturach politycznych na przykładzie państw Unii Europejskiej, Wydawnictwo Adam Marszałek, Torun 2007, s. 62. Prawa wyborcze w Polsce kobiety otrzymały w 1918 roku.

11 Op.cit. S. de Beauvoir, Druga płeć, Wydawnictwo Czarna Owca, Warszawa 2014, s. 11. 
i tzw. baby boom w Ameryce ${ }^{12}$. Simone de Beauvoir zaliczała się do pierwszej fali feminizmu, ale ideowo nawiązywała do postulatów i kierunków drugiej fali. Niektórzy badacze uważają, że wydarzeniem rozpoczynającym drugą falę był protest związany z wyborami miss Ameryka w 1968 i 1969 roku. W tym czasie istotny wpływ na późniejsze ruchy ideowe miała Margared Mead, która między innymi badała życie ludów pierwotnych na Samoa. Stwierdziła ona, że standaryzacja ogranicza ludzi i społeczeństwo ${ }^{13}$. Robert Stoller jako jeden z pierwszych badaczy podkreślał różnicę płci biologicznej i płci społeczno-kulturowej. W swojej publikacji: Sex and Gender: The Development of Masculinity and Femininity skoncentrował się na osobach, które wykazywały się zaburzeniami psychoseksualnymi. Rozdzielenie płci biologicznej i kulturowej było początkiem zainteresowania środowiska badaczy i ruchów feministycznych zagadnieniem gender. Na nowo zdefiniowany został termin gender, który dotychczas stosowany był do określenia rodzaju gramatycznego ${ }^{14}$. Jako pierwsza tego terminu użyła w kontekście feministycznym Anne Oakley w 1972 roku. Zdefiniowała i rozpowszechniła różnicę między płcią biologiczną - sex, a terminem gender, czyli płcią społeczno-kulturową ${ }^{15}$. Na rozwój tych poglądów miały przemożny wpływ psychoanaliza Sigmunta Freuda, badania Johna Moneya, Wilhelma Reicha, Anke Ehrhard i następców, między innymi Alfreda Kinsleya, Jacques-Marie-Émile Lacana. Badania i poglądy wielu $\mathrm{z}$ nich zostały w znaczącym stopniu odrzucone lub obalone, ale jak pisze Zbigniew Lew-Starowicz o kontrowersyjnych badaniach Kinseya: ,jego nazwisko wyryte jest w świadomości seksuologów. (...) Przed nim był Freud. (...) Jego prace wywołały przełom w mentalności i przyczyniły się do późniejszej rewolucji seksualnej”"16. W feminizmie drugiej fali zaczęto głośno wypowiadać się przeciw wartości małżeństwa, uważając model heteroseksualny za przestarzały, zachwalano przejęcie kontroli nad „reprodukcją” i nowe postulaty dotyczące kontroli i środków „reprodukcji”. Shulamith Firestone głosiła, iż klasy płciowe są pierwotne i należy uwolnić kobiety z tyranii biologii i dominacji mężczyzn ${ }^{17}$. Betty Friedan podjęła krytykę panujących relacji rodzinnych i roli kobiet w amerykańskich domach w połowie XX wieku, podkreślając dominującą rolę mężczyzn i panujący patriarchat. Friedan wypowiadała się w imieniu kobiet, twierdząc, iż nie akceptują one

12 Tamże, J. Hannam, Feminizm, s. 145.

13 Sex and Temperament in Three Primitive Societies, jej tezy zostały zweryfikowane i obalone w pracy D. Freemana Margaret Mead and Samoa: The Making and Unmaking of an Anthropological Myth.

14 Por. A. Burzyńska, M.P. Markowski, Teoria literatury XX wieku, Wydawnictwo Znak, Kraków 2006, s. 442.

15 Tamże, s. 445.

16 www.wysokieobcasy.pl/wysokie-obcasy/1,966950,2580757.html (1.10.2021).

17 Por. S. Firestone, The Dialectic of Sex: The Case for Feminist Revolution, Wydawnictwo William Morrow and Company, Inc., New York 1970, s. 145-190. 
obowiązującego podziału ról $\mathrm{w}$ rodzinie ${ }^{18}$. Luce Irigaray przyjęła inny kierunek, nie zgadzając się z wizją Simone de Beauvoir, nie porzucała kobiecości, zapragnęła, aby kobieta odnalazła kobiecą podmiotowość. Nie popadała w nihilistyczną wizję śmierci, ale przyjęła odnowę, uważając, że różnica płci jest kwestią centralną ${ }^{19}$. W nurcie feminizmu drugiej fali powstały różne kierunki tej myśli, nawiązując i akcentując różne punkty widzenia. W ramach tego ruchu można wyodrębnić feminizm marksistowski, liberalny oraz radykalny. Szczególnie ten ostatni miał duże znaczenie w późniejszych propozycjach wprowadzenia postulatów feminizmu drugiej fali w edukacji, w tym edukacji seksualnej, aborcji, obalenie patriarchatu i heteronormatywności ${ }^{20}$. W 1973 roku Amerykańskie Towarzystwo Psychiatryczne (APT) przyjęło w trakcie obrad decyzję, która wykreśliła homoseksualizm z podręcznika zaburzeń psychicznych DSM ${ }^{21}$. W latach 70. nastąpił radykalny okres buntów, nazwany rewolucją seksualną, który wyrażał się między innymi w tzw. wolnej miłości, zakładaniu komun, w których traktowano tradycyjny związek małżeński jako przestarzały i ograniczający. Idee wolnej miłości i prawa reprodukcyjne zdobywały coraz większą akceptację i docierały do głównego nurtu tzn. mainstreamu $\mathrm{w}$ edukacji, polityce, gospodarce, prawie i kulturze. Wyrazem tego było zorganizowanie pierwszej konferencji w sprawie kobiet w Meksyku w 1975 roku. Na kolejnych konferencjach proponowano wiele pozytywnych kwestii, ale również forsowano kontrowersyjnie postulaty dotyczące obalenia tradycyjnego modelu rodziny oraz kontroli środków reprodukcyjnych. Przykładem wprowadzenia propozycji sprzeciwiających się wartościom chrześcijańskim była konferencja w Pekinie w 1995 roku, na której postulowano wprowadzenie kwestii związanych ze zdrowiem reprodukcyjnym, pojęcie gender i gender mainstream ${ }^{22}$. Konferencje i deklaracje nie są dokumentami wiążącymi prawnie państwa, ale silnie oddziaływują na organizacje międzynarodowe i pozarządowe, które włączają programy z konferencji do różnych dziedzin życia społecznego, kulturalnego i prawnego. Między innymi pod wpływem toczących się dyskusji została wyeliminowana

18 Por. B. Friedan, The Feminine Mystique, Wydawnictwo Dell Publishing Co., Inc, New York 1974, s. 326-327.

19 Por. O. Cielemęcka, Od różnicy do etyki różnicy. Feministyczna filozofia Lucy Irigaray, „Etyka”, 45/2012, s. 73-76.

20 Por. S. Kuźma-Markowska, Druga fala, w: Encyklopedia gender: płeć w kulturze, Wydawnictwo Czarna Owca, Warszawa 2014, s. 97-99.

21 Por. Diagnostic and Statistical Manual of Mental Disorders (Third Edition), Wydawnictwo The American Psychiatric Association, Washington 1980, (DSMIII), (DSMII - 1968r.). W DSM II homoseksualizm występował jako seksualna dewiacja, w DSM III już nie występuje. World Health Organization - WHO 17 maja 1990 roku usunęła homoseksualizm z Międzynarodowej Klasyfikacji Chorób. Http://www.euro.who.int/en/health-topics/health-determinants/gender/news/ news/2011/05/stop-discrimination-against-homosexual-men-and-women (1.10.2021).

22 http://www.tus.org.pl/uploads/dokumenty/raport_czwartej_swiatowej_konferencji_w_sprawie_kobiet_pekin_1995.pdf(1.10.2021). 
definicja dotycząca małżeństwa z Karty Praw Podstawowych Unii Europejskiej, która znalazła się w Powszechnej Deklaracji Praw Człowieka. W Karcie Praw Podstawowych Unii Europejskiej nie ma już definicji małżeństwa, jako związku mężczyzny i kobiety, jest natomiast nacisk na kwestię dyskryminacji ${ }^{23}$.

Idee drugiej fali stały się podłożem do rozpoczęcia trzeciej fali feminizmu, w latach 90. XX wieku²4. Jako pierwsza pojęcie trzeciej fali feminizmu użyła Rebecca Walker, wypowiadając się na łamach czasopisma „Ms Magazine”25. Feminizm trzeciej fali włączył do swojego głównego nurtu dotychczas pomijane lub mało eksplorowane kwestie mniejszości rasowych, homoseksualizmu, krajów trzeciego świata, głównie kierując się zasadą „,wielości i różnorodności kobiecych światów" ${ }^{\prime 26}$. Niezadowolenie środowiska powolnym wprowadzaniem propozycji wynikających z drugiej fali feminizmu skłaniało działaczy do większej różnorodności i radykalizacji postulatów oraz włączenia idei gender do wszystkich etapów działalności. W 1990 roku na Uniwersytecie Kalifornia, Teresa de Lauretis wymyśliła tytuł konferencji "queer theory", termin ten był dotychczas interpretowany jako pejoratywny i obraźliwy ${ }^{27}$. Pojęciem queer określano osobę dziwną, cudaczną, tak więc negatywne określenie zmieniło znaczenie, nastąpiło nowe użycie pojęć, nazwane subwersją ${ }^{28}$. Wśród innych badaczy można wymienić między innymi Evę Kosofski Sedwick, Dianę Fuss, Jonathana Dellimore, Christine Delphy, Judith Butler. Liderem jest Judith Butler, która jako pierwsza systematycznie i konsekwentnie rozwija i opisuje ideę queer. Butler zainspirowana performatywną funkcją języka Johna L. Austina, przeniosła ją na pojęcie płci kulturowo-społecznej ${ }^{29}$. Opierała się ona na „ojcu queer” Michelu Foucalt, a także na filozofach postmodernizmu. Przesunęła granicę między egzystencją, a esencją, czyli płcią biologiczną (sex) i płcią kulturowo-społeczną (gender), skrajnie w kierunku tej drugiej. Wyraźnie podkreśla to inna badaczka Christine Delphy, uważając, że na

${ }^{23}$ Por. S. Ewetrowski, Karta Praw Podstawowych Unii Europejskiej w kontekście gender mainstreaming, w: Idea gender jako wyzwanie dla teologii, Wydawnictwo Hosianum, Olsztyn 2009, s. $188-194$,

24 Por. J. Helios, W. Jedlecka, Urzeczywistnianie idei feminizmu w ogólnoświatowym dyskursie o kobietach, Wydawnictwo Uniwersytetu Wrocławskiego, Wrocław 2018, s.101. Część badaczy uważa, że w dalszym ciągu znajdujemy się w drugiej fali feminizmu, część uważa, iż jesteśmy w trzeciej fali, istnieje też grupa osób, która wskazuje na początki czwartej fali feminizmu.

${ }_{25}$ K. Aune, R. Holyoak, Navigating the third wave: Contemporary UK feminist activists and 'thirdwave feminism ,s. 5, https://pure.coventry.ac.uk/ws/portalfiles/portal/12570762/navigatingcomb. $\operatorname{pdf}(1.10 .2021)$.

26 A. Burzyńska, Teoria literatury XX wieku, Wydawnictwo Znak, Kraków 2005, s. 388.

27 Por. D. M. Halperin, The Normalization of Queer Theory, ,Journal of Homosexuality”, 45(2-4), 2003, s. 339-340.

28 J. Butler, Uwikłani w płeć. Feminizm i polityka tożsamości, Wydawnictwo Krytyki Politycznej, Warszawa 2008, s. 259.

29 Por. J. L.Austin, Mówienie i poznanie. Rozprawy i wyklady filozoficzne, Wydawnictwo PWN, Warszawa 1993, s. 314. 
płeć biologiczną należy patrzeć z perspektywy badań genderowych ${ }^{30}$. Konstruktywistyczne ujęcie płci oznacza odrzucenie oddziaływania płci biologicznej i przyjęcie płci społeczno-kulturowej jako głównej lub jedynej kształtującej podmiotową tożsamość płciową i orientację psychoseksualną ${ }^{31}$. Warto zauważyć, że w pewnych środowiskach esencjonalista lub osoba, która uważa, iż płeć biologiczna jest wiodąca w kształtowaniu orientacji seksualnej i tożsamości płciowej, określana jest jako „niemal inwektywa”32. Butler czyni radykalny konstrukt z płci biologicznej, rozważając i umieszczając ją w „strefie przeddyskursywnej”, jak stwierdza „skoro można podważyć niezmienny charakter biologicznej płci, to może konstrukt ten, który zwiemy „biologiczną płcią”, jest tak samo konstruktem kultury jak kulturowa płeć; otóż może biologiczna płeć zawsze była jak najbardziej kulturową płcią. To znaczy, że w ogóle nie istnieje rozróżnienie na płeć biologiczną i kulturową"33. Butler, odwołując się do Foucalta i próbując wyzwolić się z opresji patriarchalnej, przechodzi do performatywności rodzajowej. Głównym celem takiego zabiegu jest podkreślenie seksualnej wielości i różnorodności, w której heteroseksualność jest jedną z wielu możliwych preferencji seksualnych. Zabieg ten dowartościowuje nienormatywność seksualną i jednocześnie umniejsza normatywność, czyli naturę kobiety i mężczyzny i ich relację heteroseksualną. Płciowość jest więc kulturowym dyskursem, który odbywa się poprzez odtwarzanie performatywnych konwencji. „Akty performatywne są odmianą mowy autorytarnej, większość performatywów, to na przykład wypowiedzi, które stanowią jednocześnie moc wiążącą i wykonują pewną czynność ${ }^{34}$. Performatywność nie jest zwykłym przedstawieniem lub grą, ale działaniem, które powtórzone, praktykowane i określone, działa w pewnej historii i konwencji. Natomiast ,ja” powstaje, jeśli zostanie ,interpolowane”, nazwane i określone ${ }^{35}$. Queer niejako ma rozsadzać

30 Por. A. Burzyńska. M.P. Markowski, Teoria, s. 456.

31 Por. tamże, s.448.W gender i queer uwzględnia się wzajemną relację między płcią biologiczną i społeczno-kulturową oraz ich wpływ na tożsamość płciową człowieka, orientację, preferencje, rolę i zachowania seksualne. Przyjmuje się, że istnieją trzy główne ujęcia takiego oddziaływania: 1. Esencjalistyczne - płeć biologiczna jest pierwotna i z niej wynika płeć kulturowa. 2. Umiarkowane, które postuluje, że płeć biologiczna jest pierwotna, ale to płeć kulturowa jest ważniejsza. 3. Radykalne ujęcie - konstruktywistyczne, które uznaje, że płeć kulturowa kształtuje tożsamość płciową i orientację seksualną, odrzuca wpływ płci biologicznej.

32 W. Śmieja, Przeciw konstrukcjonistom. Teoria queer i jej krytycy, „Przestrzenie Teorii” 13, 2010, s. 226.

33 J. Butler, Uwiktani w pleć. Feminizm i polityka tożsamości, Wydawnictwo Krytyki Politycznej, Warszawa 2008, s. 52-53.

34 J. Butler, Bodies that Matter, Wydawnictwo Roudedge, New York 1993, s. 225. Tłumaczenie własne.

35 S. Wróbel, Efekt interpolacji, Wydawnictwo Polskiej Akademii Nauk, Warszawa 2012, s. 22-33 „(...) Funkcją ideologii lub dyskursu jest bowiem przekształcanie biologicznych jednostek w podmioty (...) Efekt interpelacji to zatem efekt podwojenia: z sytuacji bycia ciałem jednostka staje się ciałem oraz ideą ciała." 
seksualną normatywność, ma otwierać się na nowe praktyki poprzez performatywność publiczną i prywatną. „Queer teoria stanowi dla nauki prawdziwe wyzwanie, ponieważ w dużo większym stopniu niż perspektywa gender - obejmuje swym zainteresowaniem tematy tabu, tematy «nieciekawe» dla «prawdziwych» naukowców, tj. dotyczy seksualności i ciała"36. Pojęcie queer nie opisuje w pełni reprezentantów, ma zostać przypadkowe, obalalne przez nowe, nieokreślone spojrzenia, ma obnażać historyczność i konwencje. Termin ten ma być nieokreślony, niedefiniowany, ma afirmować inność, różnorodność, występować przeciwko zachowaniom, ocenie i kontroli zachowań seksualnych ${ }^{37}$. Działania wynikające z tych poglądów mają być otwarte na nowe przestrzenie i doświadczenia, mają być afirmacją inności i dowartościowaniem osób tak postępujących oraz być zachętą do bycia innym ${ }^{38}$.

\section{PODSTAWY FILOZOFICZNE QUEER A NAUKA KOŚCIOLA KATOLICKIEGO}

Nauka Kościoła katolickiego dużą wagę poświęca zagadnieniu człowieka, jego spotkaniu z Bogiem i relacjom międzyludzkim. Antropologia (gr. őv $\theta \rho \omega \pi o \varsigma-$

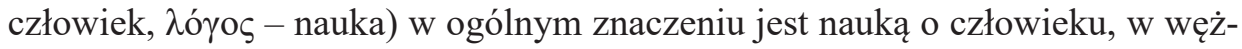
szym jako antropologia religijna (teologiczna), dotyczy godności człowieka w relacji do Boga, którą odnajdujemy w stwierdzeniu: ,Chrystus i historia zbawienia to pierwsza zasada antropologiczna"39. Antropologia chrześcijańska, jak podkreśla Marian Jaworski, powinna zmierzać w kierunkach: fenomenologiczno-egzystencjalnym oraz metafizycznym ${ }^{40}$. Jest to droga, którą wytycza Konstytucja duszpasterska o Kościele w świecie współczesnym Gaudium et spes, która akcentuje objawienie Bożego zamysłu i światła Bożej myśli oraz zwraca uwagę na kierowanie człowieka i jego ,umysłu do rozwoju w pełni ludzkiego"41. W ten sposób dokument podkreśla godność człowieka i jego życie w wymiarze egzy-

36 E. Zierkiewicz, O konieczności właczenia problematyki płci kulturowej i orientacji seksualnej do zawodowego przygotowania pedagogów - doradców, w: Odmiany odmieńca. Mniejszościowe orientacje seksualne w perspektywie gender, red. T. Basiuk, D. Ferens i in., Wydawnictwo Naukowe „Śląsk”, Katowice 2002, s. 144.

37 Por. J. Mizielińska, Pteć, ciało, seksualność. Od feminizmu do teorii queer, Wydawnictwo Univerisitas, Kraków 2006, s. 116.

38 Por. I. Iwasiów, Gender dla średniozaawansowanych, Wydawnictwo W.A.B., Warszawa 2004, s. 91.

39 L. Kuc, Zagadnienie antropologii chrześcijańskiej, „Studia Theologica Varsaviensia”, 9/2 1971, str. 101.

40 Por. M. Jaworski, Teologia a antropologia. Aspekt filozoficzny, „Analecta Cracoviensia”, 1971, s. 60 .

41 KDK 11,12 . 
stencjalnym i jednocześnie transcendentnym. Antropologia chrześcijańska, która jest kontynuacją myśli św. Tomasza z Akwinu, podkreśla znaczenie duszy i ciała w człowieku, dowartościowując ciało i przezwyciężając wcześniejsze myślenie św. Augustyna, który przeakcentował znaczenie duszy ludzkiej. Św. Augustyn w interpretacji relacji ciała i duszy kierował się filozofią platońską i neoplatońską, która traktowała ciało jako ograniczenie, coś gorszego. W kierunku jedności ciała i duszy podąża personalizm chrześcijański, w którego centrum rozważań stawia się osobę ludzką i jej relacyjność.

Człowiek jest zatem jednością duchowo-fizyczną, ludzka duchowość wyraża się poprzez duszę i w ciele. Ciało i dusza „nie są powiązane ze sobą luźno i przygodnie i siłą narzuconą z zewnątrz, lecz stanowią naturalną całość zwaną człowiekiem”"22. „Jedność ciała i ducha jest tak głęboka, że można uważać duszę za 'formę' ciała; oznacza to, że dzięki duszy duchowej ciało utworzone z materii jest ciałem żywym i ludzkim, duch i materia w człowieku nie są dwoma połączonymi nurtami, ale ich zjednoczenie tworzy jedną naturę"*3. Obydwa elementy, a więc dusza i ciało stanowią moje ,ja" wspólnie tworząc osobę, a jednocześnie nie są one tożsame, stanowią one ,integralną część natury ludzkiej”" ${ }^{4}$. Natura (łac. nascor - rodzić się; naturus - mający się urodzić) to coś, co jest związane z istotą człowieka, coś co czyni człowieka człowiekiem, jest to coś przyrodzone i dziedziczone ${ }^{45}$. Na pierwszych stronach Pisma Świętego znajduje się opis stworzenia człowieka na obraz i podobieństwo Boga. „Tego pierwszego człowieka Biblia nazywa właśnie 'człowiekiem' (adam), lecz od chwili stworzenia pierwszej kobiety zaczyna go nazywać mężczyzną 'is', w relacji do 'issa' - kobiety (bo właśnie z mężczyzny 'is' została wzięta)" "46 . Bóg stwarzając człowieka uczynił go koroną wszystkich stworzeń, „uczynił Bóg człowieka niewiele mniejszym od istot niebieskich, chwałą i czcią go uwiecznił, obdarzył władzą" (Ps 8,6). Człowiek realizuje siebie i tworzy swoje otoczenie poprzez relacje z innymi. Dzięki odpowiedzialnej miłości tworzy i buduje trwałe związki, może realizować małżeńską kreację miłości dwojga osób. Człowiek dzięki cechom płciowym, na płaszczyźnie biologicznej, duchowej i psychicznej staje się kobietą lub mężczyzną - konstytuuje się jako „Ten” lub „Ta”. Osoba jest w swoich wyborach wolna, ale też stworzona do miłości i dla miłości. W ten sposób może w pełni realizować siebie, dokonywać wyborów

42 W. Granat, Fenomen człowieka. U podstaw humanizmu chrześcijańskiego, Wydawnictwo Katolickiego Uniwersytetu Lubelskiego, Lublin 2007, s. 409.

43 Jan Paweł II, Mężczyzna i niewiasta stworzyt ich, Wydawnictwo Katolickiego Uniwersytetu Lubelskiego, Lublin 1981, s. 33.

44 S. Kowalczyk, Zarys filozofii czlowieka, Wydawnictwo i Drukarnia Diecezji Sandomierskiej, Sandomierz 2002, s. 223.

45 Por. M.A. Krąpiec, Człowiek jako osoba, Wydawnictwo: Polskie Towarzystwo Tomasza z Akwinu, Lublin 2009, s. 153-156.

46 Jan Paweł II, Mężczyzna i niewiasta stworzyt ich, s. 24. 
i poszukiwać prawdy. „Miłość w tym znaczeniu jest samą osnową moralnej powinności, istotą moralnego obowiązku, czyli naczelną zasadą etyczną, zasadą współbycia i współdziałania osób" ${ }^{\text {47 }}$.

Początek kryzysu antropologii opartej na katolickich wartościach i rozłamu chrześcijaństwa, jako systematycznego działania w filozofii nowożytnej, odnajdujemy w poglądach Martina Lutra. W swoim kluczowym dziele $O$ niewolnej woli - De Servo Arbitro podejmuje on polemikę z dziełem $O$ wolnej woli - De libero arbitro. „Bóg, twierdził niemiecki reformator, działa, kiedy chce i jak chce, bez przyczyny ani powodu, ponieważ do Jego natury przynależy wszechmoc. Taki Bóg w swojej wolności narzuca człowiekowi konieczność" ${ }^{48}$. Jak powiada Luter, człowiek jest jak , pociągowe bydlę”, postępuje tak jak chce ten, który go dosiada, Bóg lub szatan ${ }^{49}$. Negatywne oddziaływanie myśli Lutra i jego sformułowań odnajdujemy w późniejszych poglądach filozofów, co potwierdza „słuszność diagnoz, które wskazywały na protestantyzm i rozwój industrializacji (protestantyzm jako model sprzyjający industrializacji i rozwojowi kapitalizmu) jako na główne czynniki przyśpieszające sekularyzację" ${ }^{50}$. Jeszcze w idealizmie Hegla znajdujemy ideę boga jako ducha absolutnego, który podlega rozwojowi. W najważniejszej publikacji Fenomenologia ducha pisze on: „Absolutna istota (...) zstąpiła wskutek tego z wyżyn swej wiecznej prostej niezłożoności (...), osiągnęła ona dopiero dzięki temu swój szczebel istoty najwyższej”"51. Bóg Hegla potrzebuje świata i ludzi, by stać się w pełni bogiem, tylko że taki bóg nie jest doskonały i absolutny, a więc można wyciągnąć wnioski, że nie jest on bogiem, a na pewno nie pojęciem Boga w nauce Kościoła katolickiego. Hegel rozważa prawo natury, podkreśla jego dwuznaczność interpretacji i podważa jego zastosowanie, uważając iż „prawo i wszystkie jego określenia opierają się (...) na wolnej osobowości, na samookreśleniu, będącej raczej przeciwieństwem określenia naturalnego (...) gwałtem i bezprawiem (...), należy z niego wyjść" 52 . Otwiera przestrzeń do dyskusji o prawie naturalnym, którą w przyszłości podejmie wielu myślicieli i ideologów.

Poglądy Karola Marksa i Fryderyka Engelsa idą jeszcze dalej, w filozofii materializmu dialektycznego eliminowali oni pojęcie Boga i zastępowali je pojęciem materii, człowieka uważali za produkt; ,,społeczeństwo produkuje człowie-

47 T. Styczeń, Urodziteś się, by kochać, Wydawnictwo Katolickiego Uniwersytetu Lubelskiego, Lublin 1993, s. 70.

48 J. Bujak, Marcina Lutra koncepcja ,niewolnej woli” w świetle doktryny Kościoła katolickiego, „Lódzkie Studia Teologiczne”, 2012, nr 21, s. 40.

49 Por. M. Luter, O niewolnej woli - De Servo Arbitro, nr 635, http://luter2017.pl/wp - content/ uploads/pdf/ONiewolnejWoli.pdf (1.10.2021).

50 K. Szocik, Ateizm filozoficzny. Zarys historii i krytyka neotomistyczna, Zakład Wydawniczy „Nomos”, Kraków 2014, s.356.

51 G. W. F. Hegel, Fenomenologia ducha, t. II, Wydawnictwo PWN, Warszawa 1965 s. 368.

52 Tenże, Encyklopedia nauk filozoficznych, Wydawnictwo PWN, Warszawa 2014, s 505. 
ka"53. Wypowiadali się oni o relacji kobiety do mężczyzny, ich wzajemnych antagonizmach, przenosząc walkę klas na walkę między płciami, podważając wartość związków monogamicznych: „Występuje ono jako ujarzmienie jednej płci przez drugą, jako ogłoszenie niesłychanego dotąd w całej poprzedzającej historji zatargu pomiędzy płciami. (...) Pierwsze przeciwieństwo klasowe, występujące $\mathrm{w}$ historji, przypada wraz z rozwinięciem się antagonizmu między mężczyzną a kobietą w jednożeństwie" ${ }^{54}$. Engels uważał, że monogeniczny związek jest formą ujarzmiania i ucisku kobiet przez mężczyzn i należy to zmienić, a dokonać tego można dzięki zniesieniu podstaw chrześcijaństwa. Pisał on: „Tajemnicą Świętej Rodziny jest ziemska rodzina. Aby doprowadzić do zniknięcia tej pierwszej, trzeba unicestwić drugą - teoretycznie i praktycznie"55.

Ideologia marksizmu jest redukcjonizmem antropologicznym, w którym społeczeństwo jest priorytetem i znajduje się ponad jednostką, człowiek jest zatem cząstką kolektywu. Podmiot, człowiek jest depersonalizowany, negowana jest jego wolność, sumienie i nieśmiertelność ${ }^{56}$. „Traktując psychoanalizę jako pewien model antropologiczny, rozświetlając założenia ontologiczne i epistemologiczne myśli ojca psychoanalizy, można wykazać, że stanowisko freudyzmu jest zbieżne $\mathrm{z}$ teorią queer w kwestii niestabilności tożsamości podmiotu ('pęknięcie w podmiocie'), odrzuca i redukuje człowieka dehumanizując osobę ludzką" ${ }^{57}$. Sigmund Freud redukuje człowieka do kontekstu popędowo-instynktowego, a więc ekspresji biologicznych popędów, w szczególności do popędu seksualnego. Odrzuca on wyższe wartości, jakimi są miłość, sumienie, ethos, sprawiedliwość, to „zasada rozkoszy ustanawia cel życia" ${ }^{\prime 5}$.

Judith Butler sięga głębiej, porównuje myśl Michela Foucaulta z wypowiedziami Nietzschego i zastanawia się nad ,pojęciem łańcucha znaków, które można rozumieć jako utopijną inwestycję w dyskurs, powracającą w koncepcji władzy dyskursywnej Foucaulta" 59 . Friedrich Wilhelm Nietzsche w Tako rzecze Zaratustra koncentruje się na wizji materialistycznej i biologicznej, uważając człowieka za tak zwane oswojone zwierzę. W Antychryście i Woli mocy odrzucał metafizykę,

53 K. Marks, Rękopisy ekonomiczno-filozoficzne, w: Marks-Engels, Dzieła, Wydawnictwo „Książka i Wiedza", Warszawa 1960, t. 1, s. 579.

${ }^{54}$ F. Engels, Pochodzenie rodziny, własności prywatnej i państwa, Wydawnictwo „Życie”, Kraków 1912, s. 75-76.

55 G.. Kuby, Globalna rewolucja, s. 36.

56 Por. S. Kowalczyk, Zarys filozofii człowieka, Wydawnictwo Diecezjalne, Sandomierz 2002, s. $9-10$.

57 K. Szmaglińska, Aktualność Sigmunda Freuda: aporie teorii queer i ich przezwyciężenie, „Folia Philosophica", 33, 2015, s. 285-286.

58 Por. Z. Freud, Pisma Społeczne. Dzieła. Tom IV, Wydawnictwo KR, Warszawa 1998, s.174.

59 J. Butler, Bodies that Matter, Wydawnictwo Roudedge, New York 1993, s. 223. Tłumaczenie własne. 
pojęcie prawdy, o której mówił, że jest „,do niczego nieprzydatna” ${ }^{60}$. Jednocześnie prawdę relatywizuje uważając, że prawda jest tworzona, nie poznawalna. Odrzucał chrześcijaństwo, miłosierdzie i miłość, uważając, że miłość czyni człowieka słabym. Dla Nietzschego liczyła się „wola mocy” - tak zwany nadczłowiek ${ }^{61}$. Butler odrzuca w stanowczy sposób substancjalność, a więc byt, jego podmiotowość, koncentruje się zatem na procesie i działaniu, w swoim rozumowaniu podąża za niemieckim filozofem, który stwierdza, że „Nie ma żadnego bytu poza czynieniem, działaniem, stawaniem się; 'czyniciel' jest tylko zmyśleniem do czynienia dodanym - czynność jest wszystkim" ${ }^{2}$.

Queer mocno czerpie z filozofii Nietzschego, co wyraził Randall Halle ,wiedzę, że o ile nie ma znaczenia, czy Nietzsche był homoseksualistą, to jednak książka i twórczość Nietzschego są zasadniczo queer. Nietzsche przedstawił fundamentalne paradygmaty wiedzy queer" ${ }^{3}$. Kolejnym filozofem, którego poglądy są fundamentem idei queer jest Jean-Paul Sartre. W życiu prywatnym był on partnerem feministki Simone de Beauvoir. Myśl jego jest głęboko zakorzeniona w filozofii egzystencjalnej. Był on czołowym przedstawicielem nurtu egzystencjalizmu ateistycznego, jego sformułowanie ,istnienie poprzedza istotę rzeczy (egzystencja poprzedza esencję)" wrosło głęboko w idee gender i queer ${ }^{64}$. Myśl Sartre’a oznacza, że „człowiek jest wolny i że nie istnieje żadna idealna natura ludzka”, a więc wszelka idea dobra i wartości, ,wszystko jest dozwolone”. Moralność zostaje odrzucona, to ,ja" odpowiadam za swoje czyny, czuję się przy tym osamotniony, zdając się na swoje uczucia, które „,budujemy poprzez czyny”, tak więc człowiek sam siebie tworzy i czyni ${ }^{65}$.

Herbert Marcuse - czołowy przedstawiciel szkoły frankfurckiej, w Człowieku jednowymiarowym koresponduje z marksistowskim zniesieniem pracy, uważa, że

${ }_{60}$ Por. F. Nietzsche, Wola mocy, Wydawnictwo Visa-a-Vis Etiuda, Kraków 2015, s. 302.

${ }^{61}$ Por. V. E. Frankl, „Homo Patiens”, Wydawnictwo PAX, Warszawa 1971, s. 9. „Albowiem istota nihilizmu nie polega, jak się zwykło sądzić, na tym, że zaprzecza on bytowi w ogóle; właściwie nie kwestionuje on samego bytu — albo raczej istnienia bytu, lecz jego sens".

62 J. Butler, Uwiktani w pteć. Feminizm i polityka tożsamości, Wydawnictwo Krytyki Politycznej, Warszawa 2008, s. 80-81. „Zatem, skoro nie ma trwałości substancji, nie może w sposób trwały istnieć tożsamość osobowa ani płciowa, a to, co w tym kontekście obserwujemy, jest jedynie wynikiem performatywnych konsekwencji języka i kultury. (...) Jeśli nie ma trwałości substancji - to nie ma podstaw do wyodrębnienia jednostek, rzeczywistość należy traktować jako skrajnie holistyczną, nierozróżnialną całość. Nie można wyodrębnić autonomicznych jednostek ani żadnych innych trwałych elementów struktury społecznej. A skoro tak, to niczym nieuzasadniony staje się postulat Butler, aby przyznawać określone prawa mniejszościom seksualnym, tak jej bliskie", A. Margasiński, Antropologia Judith Butler a jej konsekwencje edukacyjno-wychowawcze, w: „Pedagogika” 2016, t. XXV, s. 412.

63 R. Halle, Queer Social Philosophy: Critical Readings from Kant to Adorno, Wydawnictwo University of Illinois Press, Chicago 2004, s. 175. Tłumaczenie własne.

64 J. P. Sartre, Egzystencjalizm jest humanizmem, Wydawnictwo Muza S.A., Warszawa 1998, s. 23.

65 Tamże, s. 43-45. 
praca powinna być zastąpiona, zautomatyzowana, po to, by człowiek miał więcej czasu. Ludzie według Marcuse'a stracili ducha rewolucji, natomiast odnajdują się w swoich potrzebach - towarach, wyposażeniu i sprzętach. Wolne społeczeństwo to „wolność od ekonomii (...) wolność od codziennej walki o byt (...) wolność od polityki”" ${ }^{\prime 6}$. Wolność według Marcus'a wpisuje się w definicję wolności Isaaka Berlina, który w dwóch koncepcjach wolności podkreśla przede wszystkim koncepcję wolności „od” (negatywnej), co dobitnie wyraża jego sformułowanie „Wolność to (...) usuwanie przeszkód dla mojej woli, jakie by one nie były - oporu natury, moich niesfornych namiętności, nieracjonalnych instytucji, przeciwstawnych pragnień i zachowań innych ludzi. (...) Także i im, jeśli potrafię, muszę narzucać swą wolę, „uformować” ich na swoją modłę, rozdać im role do gry w mojej sztuce" ${ }^{67}$. Marcuse proponuje wzbudzić nową wrażliwość człowieka, dla którego wzorem będą archetypy mitologiczne, tak aby nastąpiło jego spełnienie. Człowiek ma realizować się poprzez „uwolnienie wrodzonych sił libidynalnych" 68 . Podglądy Marcuse'a są zbieżne z poglądem queer, wyrażającym się w wolności od instytucji, wartości, normatywności, heteronormatywności i opresji patriarchalnej. Myśl Michela Foucaulta wyraża się w opresyjności systemu władzy i wiedzy, która ujarzmia, hamuje i dyskryminuje ludzkie pragnienia, w szczególności seksualność człowieka. Grupą, którą Foucault w systematyczny sposób atakuje, jest Kościół i duchowieństwo oraz normy chrześcijańskie. Foucault uważa Kościół za hamulec w wyzwoleniu człowieka. Wyraża on istotny sprzeciw wobec sakramentów, szczególnie wobec sakramentu spowiedzi, który w jego rozumieniu podporządkowuje, pozwala rządzić i sterować wiernymi. „Chrześcijańskie duszpasterstwo za podstawowy obowiązek przyjęło zadanie przepuszczenia wszystkiego, co ma związek z seksem, przez nieskończony młyn mówienia (...). Nie chodzi o zbiorową ciekawość czy wrażliwość, ani nową mentalność, lecz o mechanizm władzy, dla funkcjonowania których dyskurs o seksie stał się (...) rzeczą zasadniczą" ${ }^{69}$. Chrześcijaństwo, które określało moralne zasady obowiązujące wiernych, były dla Foucaulta zagrożeniem tożsamości i sensu, ponieważ uważa on, iż każdy musi przejść przez seks, by zrealizować siebie i swoją cielesnośćc ${ }^{70}$.

W postmodernizmie inspiracją dla queer jest filozofia wiodącego przedstawiciela - Jacques'a Derridy, prekursora poststrukturalizmu, uważanego za ,papieża” postmodernizmu ${ }^{71}$. Derrida czerpał z myśli wcześniejszych filozofów, szczególny szacunek i poważanie wyrażał wobec F. W. Nietzchego ${ }^{72}$. Derrida zaprzeczał

\footnotetext{
66 Por. H. Marcuse, Człowiek jednowymiarowy, Wydawnictwo PWN 1991, s. 21-27.

67 I. Berlin, „Dwie koncepcje wolności”, Wydawnictwo Res Publica, Warszawa 1991, s. 152.

68 H. Marcuse, Eros i cywilizacja,Wydawnictwo Muza, Warszawa 1998, s. 179.

69 M. Foucault, Historia seksualności, Wydawnictwo Czytelnik, Warszawa 1995, s. 25-28.

70 Tamże, s. 95.

71 Por. A. Szahaj, Co to jest postmodernizm, „Ethos”, 33-34/1996, s. 77-78

72 Por. A. Miś, Derrida i dekonstrukcja, w: „Sztuka i Filozofia”, 7/1993, s. 289.
} 
metafizycznemu ujęciu prawdy i wszelkim metanarracjom, krytykował wszystkie religie, naukę, kulturę i filozofię, uznając, że kultura została wyeksploatowana i nie ma nic do zaoferowania, gdyż wszystko już było i zostało zanegowane. Dekonstrukcja Derridy miała służyć wykluczaniu różnych mniejszości, które były pomijane lub odrzucane przez polityczne struktury władzy. Uważał, iż ,(..) odroczenia w języku i techniki dekonstrukcji pozwoliły zakwestionować stałość wszelkich pojęć i tożsamości" ’3 . Derrida zwrócił uwagę na cytowalność i performatywność, podkreślał, aby performatywność mogła zaistnieć, musi nastąpić „cały proces cytowania" ${ }^{74}$. W postmodernizmie pojawia się wszechogarniająca krytyka prawdy i apoteoza absolutnej wolności człowieka, nowa filozofia ma zająć się analizą znaczeń języka, hermeneutyką i pracą z tekstem ${ }^{75}$. Postmodernizm dużą uwagę skupia na kwestii różnicy i odmienności, co ma związek z relatywizacją prawdy, która jest wielopostaciowa, subiektywna, nieuchwytna. Ponowoczesność zbiega się ze zmianą postrzegania estetyki ciała, która wpisuje się w zjawisko tak zwanego „Golden Age of Porn" ${ }^{6}$. Pojawia się mocno akcentowany ekshibicjonizm i erotyzacja w różnym wydaniu, co jest wynikiem hedonistycznie nastawionego społeczeństwa do konsumowania erotyki. Jest to zbieżne z afirmacją rozkoszy Michela Foucaulta. Postmodernizm nie dąży do poszukiwania prawdy, w rozumieniu poszukiwania racjonalności, logiki, przyjmując, iż każdy ma swoją prawdę. Właściwie to nie ma prawdy, gdyż nie istnieje ,pojedyncza odpowiedź na żadne pytanie" "77. Jest to stałe poszukiwanie prawdy i moralności, które rozpoczyna się w Baumanowskiej samotności ${ }^{78}$.

\section{PODSUMOWANIE}

Można zauważyć, iż proces zmiany mentalności społecznej i kulturowej, a także przeobrażenia społeczne następowały na przestrzeni wielu lat ewolucyjnie, z przerwami na burzliwe rewolucje, w ostatnich latach rewolucyjne zmiany przyśpieszyły sięgając bardzo głęboko w tożsamość człowieka, rodziny i całego społeczeństwa. Szczególnie niepokojąco przedstawia się perspektywa i założenia queer, które

73 R. Commell, Socjologia płci. Płeć w ujęciu globalnym, Państwowe Wydawnictwo Naukowe, Warszawa 2013, s. 77-78.

74 Por. J. Mizielińska, Dekonstrukcja kobiecości, Wydawnictwo Słowo / Obraz / Terytoria, Gdańsk 2004, s. 194.

75 Por. W. Kubina, „Ogólna charakterystyka postmodernizmu : aspekt filozoficzny”, „Sympozjum” 2/2(3)/1998, s. 19-20.

76 M. Lubecki, Refleksje na temat ponowoczesności, Wydawnictwo LIBRON, Kraków 2012, s. 237.

77 Z. Melosik, Kultura, akademia i edukacja -modernistyczno/postmodernistyczne interpretacje, „Przegląd Pedagogiczny”, 1 /2011, s. 50.

78 Por. Z. Bauman, Etyka ponowoczesna, Państwowe Wydawnictwo Naukowe, Warszawa 1996, s. 84 . 
zbudowane są na nihilistycznej i antysubstancjalnej wizji człowieka, która jest istotowo różna od chrześcijańskiej antropologii. Queer jest skoncentrowane na procesie, szczególnie na psychoanalitycznej wizji seksualnej, na popędzie i wolności w niepohamowanym wyrażaniu swojego pragnienia i tożsamościowej performatyce. Człowiek queer staje się i przesuwa między poszczególnymi konwencjami, przyjmując ryzyko nieokreśloności tożsamości płciowej i orientacji psychoseksualnej, która jest szczególnie akcentowana w queer ${ }^{79}$. Idea queer odrzuca stałość wszelkich norm, szczególnie heteronormatywność, gloryfikując nienormatywność - różnorodność i równość. Podążając konsekwentnie tym tokiem rozumowania, powinniśmy odrzucić normatywność, jaką określa się osoby opisujące się pojęciem LGBT+, ponieważ nie są queer. Queer jako proces performatywny, niedający się dokładnie opisać i zdefiniować, który poszukuje kolejnych nisz nienormatywnych, sam staje się według tego rozumowania normatywny, gdyż normą staje się sam proces poszukiwania kolejnych nienormatywności. Wnioski, jakie w związku z tym się nasuwają, są następujące - queer jest nie queer. Idea queer tak jak gender, odrzuca, zgodnie z poglądami postmodernistów Boga, metanarracje, pojęcie natury i prawdy obiektywnej. Jeśli jednak chcielibyśmy przyjąć boga, to byłby on raczej tym, co napisał A.N Whitehead o Bogu, mianowicie ,jako rzeczywistość, która wyłania się w doświadczeniu pojęciowym oraz podlega procesowi spełnienia dzięki (...) doświadczeniom fizycznym, których źródłem staje się świat"80. Zważywszy, że człowiek poszukuje swojej tożsamości, która jest performatywna, pojawia się poważny problem z akceptacją i definicją małżeństwa. Przyjęcie kontekstu queer inicjuje pogląd na przyjęcie „neutralnego światopoglądu", neutralnej rodziny, edukacji i społeczeństwa. Fundamentalna miłość rodzicielska i rodzinna staje się konstruktem po wcześniejszej dekonstrukcji. Zmieniają się fundamenty, w których kluczem do ich zrozumienia jest zindywidualizowana, zdepersonalizowana osoba, wyswobodzona z tyranii biologii i zasad moralnych. Pojawia się otwartość i akceptacja związków nietrwałych, partnerskich, gdzie płciowość i seksualność jest zróżnicowana i nieciągła, skoncentrowana na moim ,ja”, a nie na wspólnym „my”. Rodzina ,jest tylko miejscem, a nie przyczyną zdarzeń", w której ,ja" realizuje swoje ja, przestrzeń własnego rozwoju ${ }^{81}$. Powstają wówczas queerowe rodziny heteronormatywne i niehetero-

79 Por. P. Gałecki, M. Pilecki, J. Rymaszewska, A. Szulc, S. Sidorowicz, J. Wciórka, Kryteria diagnostyczne zaburzeń psychicznych DSM-5, (Diagnostic and Statistical Manual of Mental Disorders DSM-5), Wydawnictwo Edra Urban \& Partner, Wrocław 2018, s. 549-551. Według Amerykańskiego Towarzystwa Psychiatrycznego w DSM - 5, transseksualizm obecnie określa się jako dysforia, natomiast w dezaktualizowanym DSM-IV-TR, transseksualizm określano jako zaburzenie tożsamości płciowej.

80 A. N Whitehead, Bóg $i$ świat, „Zagadnienia Filozoficzne w Nauce” XII/1990, s. 13-24.

${ }^{81}$ U. Beck, Społeczeństwo ryzyka. W drodze do innej nowoczesności, Wydawnictwo Naukowe SCHOLAR, Warszawa 2004, s. 164. 
normatywne, a więc quasi rodziny, związki partnerskie, rodziny patchworkowe itp.. Skoncentrowanie na swoim ciele wyraża się w spersonalizowanej medycynie, która spełnia coraz częściej indywidualne performersy i przyjmuje wymiar korekty lub modyfikacji ciała. Można odnieść to do queerowania ciała, na tyle, na ile medycyna dziś na to pozwala. Pojawia się Baumanowskie ,utowarowienie” człowieka, który staje się towarem w konsumpcyjnym świecie ${ }^{82}$. Jeden z polskich wiodących badaczy tego tematu Jacek Kochanowski uważa, iż tożsamość „osoby” i jej orientacja jest tym, o czym marzy, jedynym ograniczeniem „osoby” jest jej kreatywność i wyobraźnia ${ }^{83}$. Diagnoza sytuacji jest dalece niepokojąca, wydaje się, że drogi odwrotu już nie ma, a naciski środowiska mainstreamu są coraz mocniejsze. Mimo tego głęboko wierzę, że w imię wartości i dla wartości chrześcijańskich, opartych na fundamencie wiary i wiedzy, a także w duchu miłości, jest nadzieja zmiany tego stanu rzeczy. Przecież Jezus Chrystus powiedział znamienne słowa: „Wszystko możliwe jest dla tego, kto wierzy” (Mk 9,23). Jeśli przyjęlibyśmy postulaty i idee queer w edukacji, prawie, kulturze, w pewnym sensie wszyscy i wszystko uległoby zmianie. Gender przeniknął bardzo głęboko do świadomości społecznej, kolejny jest queer, już dziś używa się sformułowań „dobrze jest być queer" "84. Wolność jest bezcenną wartością, ale jak pisał św. Jan Paweł II, powinna ona iść w parze z odpowiedzialnością i prawdą ${ }^{85}$.

\section{Bibliografia}

Aune K., Holyoak R., Navigating the third wave: Contemporary UK feminist activists and 'third-wave feminizm. https://pure.coventry.ac.uk/ws/portalfiles/ portal/12570762/navigatingcomb.pdf (1.10.2021)

Austin J. L., Mówienie i poznanie. Rozprawy i wykłady filozoficzne, Wydawnictwo PWN, Warszawa 1993.

Bauman Z., Konsumowanie życia, Wydawnictwo Uniwersytetu Jagiellońskiego, Kraków 2009.

Bauman Z., Etyka ponowoczesna, Państwowe Wydawnictwo Naukowe, Warszawa 1996.

Beck U., Społeczeństwo ryzyka. W drodze do innej nowoczesności, Wydawnictwo Naukowe SCHOLAR, Warszawa 2004.

82 Por. Z. Bauman, Konsumowanie życia, Wydawnictwo Uniwersytetu Jagiellońskiego, Kraków 2009, s. 120.

83 Por. J. Kochanowski, Fantazmat zróżnicowany. Socjologiczne studium przemian tożsamości gejów, Wydawnictwo Universitas Kraków 2004, s. 289.

84 A. Burzyńska, M.P. Markowski, Teoria literatury, s. 445.

85 Por. K. Wojtyła, Miłość i odpowiedzialność, Wydawnictwo Katolickiego Uniwersytetu Lubelskiego, Lublin 2001, s. 84-86. 
Berlin I., Dwie koncepcje wolności, Wydawnictwo Res Publica, Warszawa 1991.

Butler, J., Uwiktani w płeć. Feminizm i polityka tożsamości, Wydawnictwo Krytyki Politycznej, Warszawa 2008.

Butler J., Bodies that Matter, Wydawnictwo Roudedge, New York 1993.

Burzyńska A., Teoria literatury XX wieku, Wydawnictwo Znak, Kraków 2005.

Bujak J., Marcina Lutra koncepcja ,niewolnej woli” w świetle doktryny Kościoła katolickiego, „Łódzkie studia teologiczne” 2012.

Beauvoir S. de, Druga płeć, Wydawnictwo Czarna Owca, Warszawa 2014.

Cielemęcka O., Od różnicy do etyki różnicy. Feministyczna filozofia Lucy Irigaray, „Etyka”, 45/2012.

Commell R., Socjologia ptci. Pteć w ujęciu globalnym, Państwowe Wydawnictwo Naukowe, Warszawa 2013.

Diagnostic and Statistical Manual of Mental Disorders, (DSM) 2, 3, 4 Amerykańskie Towarzystwo Psychiatryczne.

Engels F., Pochodzenie rodziny, własności prywatnej i państwa, Wydawnictwo „Życie”, Kraków 1912.

Ewetrowski S., Karta Praw Podstawowych Unii Europejskiej w kontekście gender mainstreaming, w: Idea gender jako wyzwanie dla teologii, Wydawnictwo Hosianum, Olsztyn 2009.

Foulcault M., Historia seksualności, Wydawnictwo Czytelnik, Warszawa 1995.

Firestone S., The Dialectic of Sex: The Case for Feminist Revolution, Wydawnictwo William Morrow and Company, Inc., New York 1970.

Frankl E., Homo Patiens, Wydawnictwo PAX, Warszawa 1971.

Friedan B., The Feminine Mystique, Wydawnictwo Dell Publishing Co., Inc, New York 1974.

Freud Z., Pisma Społeczne. Dzieła. Tom IV, Wydawnictwo KR, Warszawa 1998.

Gałecki P., Pilecki M., Rymaszewska J., Szulc A., Sidorowicz S., Wciórka J., Kryteria diagnostyczne zaburzeń psychicznych DSM-5 (Diagnostic and Statistical Manual of Mental Disorders DSM-5), Wydawnictwo Edra Urban \& Partner, Wroclaw 2018.

Granat W., Fenomen człowieka. U podstaw humanizmu chrześcijańskiego, Wydawnictwo Katolickiego Uniwersytetu Lubelskiego, Lublin 2007.

Gronold D., Hipfl B., Pedersen L., Teaching with the Third Wave New Feminists'Explorations of Teaching and Institutional Contexts, Wydawnictwo Stockholm University, Utrecht 2009.

Halle R., Queer Social Philosophy: Critical Readings from Kant to Adorno, Wydawnictwo University of Illinois Press, Chicago 2004.

Halperin D. M., The Normalization of Queer Theory, „Journal of Homosexuality", 45(2-4), 2003.

Hannam J., Feminizm, Wydawnictwo Zysk i S-ka, Poznań 2010. 
Hegel G. W. F., Encyklopedia nauk filozoficznych, PWN, Warszawa 2014.

Hegel G. W. F., Fenomenologia ducha, t. II, PWN, Warszawa 1965.

Helios J., Jedlecka W., Urzeczywistnianie idei feminizmu w ogólnoświatowym dyskursie o kobietach, Wydawnictwo Uniwersytetu Wrocławskiego, Wrocław 2018.

Iwasiów I., Gender dla średniozaawansowanych, Wydawnictwo W.A.B., Warszawa 2004.

Jan Paweł II, Mężczyzna i niewiasta stworzyt ich, Wydawnictwo Katolickiego Uniwersytetu Lubelskiego, Lublin 1981.

Jaworski M., Teologia a antropologia. Aspekt filozoficzny, „Analecta Cracoviensia", 1971.

Kochanowski J., Fantazmat zróżnicowany. Socjologiczne studium przemian tożsamości gejów, Wydawnictwo Universitas, Kraków 2004.

Kowalczyk S., Zarys filozofii człowieka, Wydawnictwo Diecezjalne, Sandomierz 2002.

Krąpiec M. A., Człowiek jako osoba, Wydawnictwo Polskie Towarzystwo Tomasza z Akwinu, Lublin 2009.

Kubina W., Ogólna charakterystyka postmodernizmu: aspekt filozoficzny, „Sympozjum”2/2(3)/1998.

Kuby G., Globalna rewolucja seksualna. Likwidacja wolności w imię wolności, Wydawnictwo Homo Dei, Kraków 2012.

Kuc L., Zagadnienie antropologii chrześcijańskiej, „Studia Theologica Varsaviensia", 9/2 1971.

Kuźma-Markowska S., Druga fala, w: Encyklopedia gender: pteć w kulturze, Wydawnictwo Czarna Owca,Warszawa 2014.

Lubecki M., Refleksje na temat ponowoczesności, Wydawnictwo LIBRON, Kraków 2012.

Luter M., O niewolnej woli - De Servo Arbitro, http://luter2017.pl/wp-content/ uploads/pdf/ONiewolnejWoli.pdf. (1.10.2021).

Łebkowska A., Gender, w: Kulturowa teoria literatury. Gtówne pojęcia i problemy, Wydawnictwo Universitas, Kraków 2012.

Marcuse H., Człowiek jednowymiarowy, PWN, Warszawa 1991.

Marcuse H., Eros i cywilizacja, Wydawnictwo Muza, Warszawa 1998.

Margasiński A., Antropologia Judith Butler a jej konsekwencje edukacyjno-wychowawcze, „Pedagogika” 2016, t. XXV.

Marks K., Rękopisy ekonomiczno-filozoficzne, w: Marks-Engels. Dzieła, t. 1, Wydawnictwo „Książka i Wiedza”, Warszawa 1960.

Melosik Z., Kultura, akademia i edukacja-modernistyczno/postmodernistyczne interpretacje, „Przegląd Pedagogiczny” 1/2011.

Miś A., Derrida i dekonstrukcja, „Sztuka i filozofia”, 7/1993. 
Mizielińska J., Dekonstrukcja kobiecości, Wydawnictwo Słowo / Obraz / Terytoria, Gdańsk 2004.

Mizielińska J., Pteć, ciało, seksualność. Od feminizmu do teorii queer, Wydawnictwo Universitas, Kraków 2006.

Nietzsche F., Wola mocy, Wydawnictwo Vis-a-Vis Etiuda, Kraków 2015.

Pius XI, Encyklika Quanta cura i Syllabus papieża Piusa XI, Wydawnictwo ANTYK, Komorów 1998.

Sartre J. P., Egzystencjalizm jest humanizmem, Wydawnictwo Muza S.A., Warszawa 1998.

Styczeń T., Urodziłeś się, by kochać, Wydawnictwo Katolickiego Uniwersytetu Lubelskiego, Lublin 1993.

Szahaj A., Co to jest postmodernizm, „Ethos”, 33-34/1996.

Szmaglińska K., Aktualność Sigmunda Freuda: aporie teorii queer i ich przezwyciężenie, „Folia Philosophica”, 33, 2015.

Szocik K., Ateizm filozoficzny. Zarys historii i krytyka neotomistyczna, Zakład Wydawniczy „Nomos”, Kraków 2014.

Śmieja W., Przeciw konstrukcjonistom. Teoria queer i jej krytycy, „Przestrzenie Teorii" 13, 2010, s. 226.

Wawrowski Ł., Polityka równych szans. Instytucjonalne mechanizmy zwiększania partycypacji kobiet w strukturach politycznych na przykładzie państw Unii Europejskiej, Wydawnictwo Adam Marszałek, Toruń 2007.

Whitehead A. N., Bóg i świat, „Zagadnienia Filozoficzne w Nauce” XII/1990.

Wieczorek B., Homoseksualizm. Przeglad światowych analiz i badań. Przyczyny, objawy, terapia, aspekty społeczne, Wydawnictwo Fronda, Warszawa 2018.

Wojtyła K., Miłość i odpowiedzialność, Wydawnictwo Katolickiego Uniwersytetu Lubelskiego, Lublin 2001.

Wojtyła K., Osoba i czyn, Wydawnictwo Polskie Towarzystwo Teologiczne, Kraków 1969.

Wróbel S., Efekt interpelacji, Wydawnictwo Polskiej Akademii Nauk, Warszawa 2012.

Zierkiewicz E., O konieczności właczenia problematyki ptci kulturowej i orientacji seksualnej do zawodowego przygotowania pedagogów-doradców, w: Odmiany odmieńca. Mniejszościowe orientacje seksualne w perspektywie gender, red. T. Basiuk, D. Ferens i in., Wydawnictwo Naukowe „Śląsk”, Katowice 2002. 